\title{
Patient readmission for surgical wound infection
}

\author{
LM Torres $^{1 *}$, RA Lacerda ${ }^{2}$, R Turrini ${ }^{2}$ \\ From International Conference on Prevention \& Infection Control (ICPIC 2011) \\ Geneva, Switzerland. 29 June - 2 July 2011
}

\section{Introduction / objectives}

Surgical site infection (SSI) rates are underestimated mainly in the absence of a successful program of post discharge surveillance. Readmissions monitoring can contribute to accurate infection rates.

\section{Methods}

Exploratory descriptive study, developed in a governmental hospital of tertiary care in Minas Gerais (Brazil), from January 2008 to December 2009. Medical records and reports of control infection practitioner of 98 patients readmitted with SSI were reviewed and the data were analyzed in relation to gender, age, co morbidities, length of staying, surgery, specialty, type of procedures, wound class, duration of surgery, SSI and micro-organisms.

\section{Results}

Readmissions occurred in patients who underwent clean and potentially contaminated surgical procedures, with co morbidities commonly among people 50 years or older. Duration of surgery did not differ from the cut point recommended by CDC. Staphylococcus aureus predominated in orthopedic procedures and Escherichia coli in general surgery, both with multi-resistance profile below the results presented in other studies.

\section{Conclusion}

Whereas the SSI occurred more frequently in clean surgeries and readmissions can provide information about the quality of care, these findings are important to control infection practitioner review the antibiotic prophylaxis protocols and surgical practices in patients undergoing clean and potentially contaminated procedures.

\section{Disclosure of interest}

None declared.

'Enfermagem Médico-Cirúrgica, Escola de Enfermagem da Universidade de São Paulo, Nova Lima, Brazil

Full list of author information is available at the end of the article

\section{Author details}

'Enfermagem Médico-Cirúrgica, Escola de Enfermagem da Universidade de São Paulo, Nova Lima, Brazil. Enfermagem Médico-Cirúrgica, Escola de Enfermagem da Universidade de São Paulo, São Paulo, Brazil.

Published: 29 June 2011

doi:10.1186/1753-6561-5-S6-P192

Cite this article as: Torres et al:: Patient readmission for surgical wound infection. BMC Proceedings 2011 5(Suppl 6):P192.

\section{Submit your next manuscript to BioMed Central and take full advantage of: \\ - Convenient online submission \\ - Thorough peer review \\ - No space constraints or color figure charges \\ - Immediate publication on acceptance \\ - Inclusion in PubMed, CAS, Scopus and Google Scholar \\ - Research which is freely available for redistribution \\ Submit your manuscript at www.biomedcentral.com/submit}

C Biomed Central

C 2011 Torres et al; licensee BioMed Central Ltd. This is an open access article distributed under the terms of the Creative Commons Attribution License (http://creativecommons.org/licenses/by/2.0), which permits unrestricted use, distribution, and reproduction in any medium, provided the original work is properly cited. 